\title{
Role of Multi-Detector Computed Tomography in Differentiation between Benign \& Malignant Cavitary Lung Lesions
}

\author{
MOHAMED A. SHERIF, M.Sc.; FATEN M. SALEM, M.D.; ABD EL-HADY M. TAHA, M.D. and \\ MOHAMED A. YOUSEF, M.D. \\ The Department of Radio-Diagnosis \& Cardiothoracic, Faculty of Medicine, Tanta University
}

\begin{abstract}
Background: In patients with cavitary lung diseases, it is crucial to detect the lesion for determining adequate treatment. Multislice CT in combination with other radiologic images is currently regarded as the most appropriate diagnostic imaging for differentiation between benign and malignant cavitary lung lesions.

Aim of Study: To evaluate the role of multi-detector computed tomography in differentiation between benign \& malignant cavitary lung lesions.

Material and Methods: The present study included 60 patients with cavitary lung lesions. They were 46 males and 14 females. Their ages ranged 15 years and 83 years with their mean age of 50 years old. All patients were subjected to radiological examination including chest $\mathrm{X}$-ray and 16 slice MDCT scanner.
\end{abstract}

Results: In this study there were 10 patients with airway diseases, 35 patients with infective lesions, and another 15 patients with tumors. The diagnosis was confirmed by (clinical follow-up, needle biopsy or bronchoscopy). In our study, 2 cases had false positive results by CT and one case had false negative results by $\mathrm{CT}$, multislice computed tomography showed sensitivity of $91 \%$, specificity of $88 \%$, and accuracy of $87 \%$.

Conclusion: MDCT is superior to plain X-ray in demonstrating the cavitary lung lesions with higher degree of clarity. It can define the exact anatomical site of the cavity, characterization of the cavitary wall and abnormalities in the surrounding lung parenchyma. It is reliable in detecting lesions in areas difficult to visualize by plain X-ray.

Key Words: Lungs - Abscess - Bronchogenic carcinomafungal ball-Plain X-ray-CT.

Correspondence to: Dr. Mohamed A. Sherif, The Department of Radio-Diagnosis \& Cardiothoracic, Faculty of Medicine, Tanta University

\section{Introduction}

CAVITARY lung lesions are defined as circumscribed air-filled areas in lung parenchyma, which may be induced by group of lung infections and necrotizing pneumonia which are characterized with multiple abscesses [1,2] .

Pulmonary cystic lesions, such as intrapulmonary cysts, sequestration or secondary infected emphysematous bullae may be difficult to differentiate, but localization of the lesion and clinical signs can indicate the appropriate diagnosis, localized pleural empyema can be distinguished by using computerized tomography scan or ultrasound [3].

There is a wide variety of pulmonary conditions with imaging features that mimic primary lung cancer, such as metastasis, benign tumors like hamartoma, mesenchymal tumors, infections like tuberculosis, aspergillosis, hydatid cyst, round pneumonia and lung abscess [4] .

New generations of computerized tomography like Multi-Detector Computerized Tomography (MDCT) have made it possible to show the morphological characteristics of these cavitary lesions and thus reaching to the correct diagnosis [5].

The margin of cavitary lesion is considered one of the main morphologic characteristics that help differentiate benign from malignant lesions on computerized tomography as malignant lesions have an irregular, ill defined, speculated margin while benign lesion tend to have a smooth, sharply well-defined edge [6] 
Plain chest radiography and computed tomography are the radiographic modalities of choice used to image the chest. Computed tomography is clearly more sensitive than plain chest radiography for the detection and characterization of pulmonary cavitary lesions [7].

MDCT is an accurate safe diagnostic modality in assessing cavitary lung lesions; it can assess size, contents, wall thickness and surrounding parenchyma [8].

The wall thickness of the cavitary lung lesion, the characteristics of its inner lining (irregular or smooth), location and its nature are important for determining the benignity of cavitary lung lesions [9].

The aim of this study was to evaluate the role of multi-detector computerized tomography in differentiation between benign and malignant cavitary lung lesions.

\section{Patients and Methods}

This study included 60 patients presented clinically by chest lesions referred to Radio-Diagnosis and Medical Imaging Department, Tanta University Hospitals, the study included 60 patients (46 males and 14 females) with their age ranging from 15 to 83 years with the mean age was between more than 40 years +2 . The duration of the study from August 2016 to April 2018.

\section{Inclusion criteria:}

- Both sexes were included.

- Patients with clinical manifestations and X-ray presented with cavitary lung lesions.

\section{Exclusion criteria:}

Patients who were contraindicated to perform CT:

- Patients with previous allergy to the contrast media.

- Renal impairment (serum creatinine $>2 \mathrm{mg} / \mathrm{dl}$ ).

- Pregnant women.

- Patients with hepatic failure.

- Patients who refused the examination.

- Informed consent was obtained from all patients after full explanation of the benefits and risks of the procedure.

- All investigations and all data of the patients were confidential.
All patients were subjected to the following:

- Full history.

- Personal, present and past history were taken.

- Complete clinical examination.

- Complete chest examination.

- Evaluation of the previous investigation and medical treatment.

Pathology confirmation by:

- Bronchoscope.

- Needle biopsy.

Radiological investigation:

- Plain chest X-ray (postero-anterior \& lateral views).

- Multidetector computed tomography with intravenous contrast.

Radiological investigation:

A- Chest radiography: Postero-anterior and lateral views were done for all cases.

- Postero-anterior view:

Positioning of the patient and film: Each patient was positioned facing the cassette. The median sagittal plane is adjusted at right angles to the middle of the film, extended neck slightly and rested on the upper border of the cassette, the back of the hands were placed on the buttocks. The shoulders were rotated forwards and pressed downwards in contact with the cassette. In female patients compressed breast against the cassette. The horizontal central ray was directed at right angles to the films at the level of fifth thoracic vertebra. Exposure was made in full normal arrested inspiration.

- Lateral view:

Positioning of the patient and film: Patient was turned to bring the side under investigation in contact with the film and the median sagittal plane is adjusted parallel to the film the arms were folded over the head. The mid axillary line was coincident with the middle of the film and the cassette is adjusted to include the apices and lower lobes to the level of 1 st lumbar vertebra. We directed the central ray at right angles to the middle of the film through the axilla in the mid axillary line.

B- Multi-detector computed tomography: Multidetector computed tomography was done for all cases using 128-slice GE machine. 


\section{Patient preparation:}

- Complete history taking to be sure that contrast media is not contraindicated.

- Fasting 4 hours before injection of contrast media.

- Oral fluids were given to the patients to make them well hydrated.

Contrast media: Was given routinely for all cases which help identification of the vascular structures in the mediastinum, hila and also the outlines of the cardiac chambers. Intravenous injection of water soluble iodinated contrast media (Iopromide 67\% 300mg iodine $/ \mathrm{ml}$ ) in a dose of 2 $\mathrm{ml} / \mathrm{kg}$ body weight, contrast media was given by automatic injector as a bolus dose; the rate of injection was about $5 \mathrm{ml} / \mathrm{sec}$.

Technique: Studies of the lung were performed at full inspiration to promote separation of vascular structures. Patients were scanned in the supine position with arms elevated above the head to prevent streak artifacts.

Frontal chest scanogram was taken from the lung apices to the upper aspect of the abdomen, slice thickness of chest computed tomography scans routinely was $5 \mathrm{~mm}$ thick, and collimation was $1 \mathrm{~mm}$.

Image interpretation: Benign lesions in this study appeared rather well defined lesions with smooth outlines, regular margins, and relatively thin wall with no speculated or irregular borders; however malignant lesions appeared rather ill defined lesions, irregular margins with thicker wall associated with speculated borders.

\section{Statistical analysis:}

Data were collected and entered to the computer using SPSS (Statistical Package for Social Science) program for statistical analysis.

Two types of statistics were done:

- Descriptive statistics: e.g. was expressed in: Number (No), percentage (\%), mean (x) and Standard Deviation (SD) and range.

-Analytical statistics:

- Mann Whitney's test was used for comparison of quantitative variables between two groups of not normally distributed data.

- Chi-square test was used to measure association between qualitative variables.

- $p$ (probability) value was considered to be of statistical significance if it is less than 0.05.
- Accuracy was represented using the terms sensitivity, specificity, positive predictive value, negative predictive value and overall accuracy.

- The significance of the results was assessed in the form of $p$-value that was differentiated into:

- Significant when $p$-value $<0.05$.

- Highly significant when $p$-value $<0.001$.

\section{Results}

As regard to demographic data, this study included 60 patients with cavitary lung lesions, the patient age in this study ranging from 15 to 83 years; the most common age group is between 40 to 50 years $(25 \%)$. As regard the difference between males and females, the present study included 46 males $(76 \%)$ and 14 females (24\%) as shown in (Table 1).

Table (1) Distribution of the patients according to the demographic data.

\begin{tabular}{|c|c|c|c|c|}
\hline \multirow{2}{*}{$\begin{array}{l}\text { Age in } \\
\text { years }\end{array}$} & \multicolumn{2}{|c|}{ Gender } & \multirow{2}{*}{ Number } & \multirow{2}{*}{$\%$} \\
\hline & Male & Female & & \\
\hline $10-20$ & 3 & & 3 & 5 \\
\hline$>20-30$ & 5 & 2 & 7 & 11.7 \\
\hline$>30-40$ & 7 & 1 & 8 & 13.3 \\
\hline$>40-50$ & 11 & 4 & 15 & 25 \\
\hline$>50-60$ & 9 & 3 & 12 & 20 \\
\hline$>60-70$ & 7 & 2 & 9 & 15 \\
\hline$>70-80$ & 3 & 1 & 4 & 6.7 \\
\hline$>80$ & 1 & 1 & 2 & 3.3 \\
\hline Total & 46 & 14 & 60 & $100 \%$ \\
\hline
\end{tabular}

As regard to clinical presentation: The patients were presented by variable clinical complaints the most common complaint is cough and seen in 45 patient $(75 \%)$ followed by dyspnea which seen in 43 patient $(71.7 \%)$ and the least complaint is chest pain in about 6 patients $(10 \%)$ as shown in (Table 2).

Table (2): Distribution according to the common complaint of all patients.

\begin{tabular}{lll}
\hline Common complaint & $\mathrm{N}$ & $\%$ \\
\hline Cough & 45 & 75 \\
Dyspnea & 43 & 71.7 \\
Expectoration & 23 & 38.3 \\
Hemoptysis & 18 & 30 \\
Fever & 33 & 55 \\
Weight loss & 14 & 23.3 \\
Chest pain & 6 & 10 \\
\hline
\end{tabular}


As regard to final diagnosis: At this study the distribution of patient according to final diagnosis is categorized into 3 groups, infective group seen in 35 patient $(58.3 \%)$ followed by neoplastic group seen in 15 patient $(25 \%)$ and airway group seen in 10 patients $(16.7 \%)$. As shown in (Table 3$)$.

Table (3): Distribution of patients according to the final diagnosis.

\begin{tabular}{lcc}
\hline Final diagnosis & Total N & $\%$ \\
\hline Airway disease: & & \\
$\quad$ Cystic bronchiectasis 3 & 10 & 16.7 \\
$\quad$ Emphysematous bullae 7 & & \\
Infective: & & \\
$\quad$ Abscess 17 & 35 & 58.3 \\
$\quad \begin{array}{l}\text { Tuberculosis 12 } \\
\text { Fungal 6 }\end{array}$ & & \\
Neoplastic: & & \\
$\quad$ Bronchogenic carcinoma 11 & 15 & 25.0 \\
$\quad$ Metastasis 4 & & \\
\hline Total & 60 & $100 \%$ \\
\hline
\end{tabular}

As regard to data confirmation, at this study: There are 29 patients, their data confirmed by bronchoscopy and represent about $(48.3 \%)$ followed by 23 patients data confirmed by clinical and laboratory follow-up (38.3\%) and 8 patients their data confirmed by biopsy (13.3\%).as shown in (Table 4).

Table (4): Distribution of the patients according to data confirmation.

\begin{tabular}{lcc}
\hline Data & Total N & $\%$ \\
\hline Clinical and laboratory follow-up: & & \\
$\quad$ Cystic bronchiectasis 6 & 23 & 38.3 \\
Emphysematous bullae 4 & & \\
Abscess 8 & & \\
$\quad$ Tuberculosis 3 & & \\
Metastasis 2 & & \\
Bronchoscopy: & 29 & 48.3 \\
$\quad$ Bronchogenic carcinoma 9 & & \\
Abscess 13 & & \\
Tuberculosis 7 & & 13.3 \\
Needle biopsy: & & \\
$\quad$ Neoplasm 7 & & \\
Fungal 1 & 8 & $100 \%$ \\
\hline Total & 60 & \\
\hline
\end{tabular}

Distribution of the patients according to wall thickness of the cavitary lesions, the most common are those having wall thickness between 4 and 10 $\mathrm{mm}$ representing (50\%), followed by those having wall thickness less than $4 \mathrm{~mm}$ representing (36.7\%) and the least having wall thickness more than 10 $\mathrm{mm}$ representing (13.3\%) as shown in (Table 5).

Table (5): Distribution of the patients according to wall thickness.

\begin{tabular}{lll}
\hline Wall thickness & $\mathrm{N}$ & $\%$ \\
\hline <4mm: & & \\
$\quad$ Cystic bronchiectasis 9 & 22 & 36.7 \\
$\quad$ Emphysematous bullae 13 & & \\
4-10mm: & & \\
$\quad$ Abscess 19 & 30 & 50.0 \\
$\quad$ Tuberculosis 10 & & \\
$\quad$ Fungal 1 & 10mm: & \\
$\quad$ Neoplasm 8 & & \\
\hline Total & 8 & 13.3 \\
\hline
\end{tabular}

In this study, air containing cavitary lung lesions are seen in 15 patients with cystic bronchiectasis represent $(25 \%)$ followed by 12 patients with emphysematous bullae represent $(20 \%)$, the least is metastasis which represent about (1.7\%). Air and fluid containing cavitary lung lesions are seen in 10 patients with abscess which represent $(16.7 \%)$ followed by 9 patients with infected cystic bronchiectasis and represent (15\%). Soft tissue containing cavitary lung lesion is seen only in one patient with fungal infection and represent about $(1.7 \%)$ as shown in (Tables 6,7).

Table (6): Distribution of the lesions according to content.

\begin{tabular}{llll}
\hline Content & Lesions & $\mathrm{N}$ & $\%$ \\
\hline Air & Cystic bronchiectasis & 15 & 25.0 \\
& Emphysematous bullae & 12 & 20.0 \\
& Bronchogenic carcinoma & 3 & 5.0 \\
& Tuberculosis & 2 & 3.3 \\
& Abscess & 7 & 11.7 \\
& Metastasis & 1 & 1.7 \\
Air and fluid & Abscess & 10 & 16.7 \\
& Infected cystic bronchiectasis & 9 & 15.0 \\
\multirow{2}{*}{ Soft tissue } & Fungal & 1 & 1.7 \\
\hline \multirow{2}{*}{ Total } & & 60 & $100 \%$ \\
\hline
\end{tabular}

Table (7): The accuracy of CT imaging in the differentiation between benign and malignant cavitary lung lesions: Shows overall accuracy of CT for diagnosis of cavitary lung lesions was $87 \%$.

\begin{tabular}{|c|c|c|c|c|}
\hline \multicolumn{4}{|c|}{ Sensitivity Specificity $p$-value Accuracy PPV } & NPP \\
\hline СТ $91 \%$ & $88 \%$ & 0.001 & $87 \% 81 \%$ & $90 \%$ \\
\hline
\end{tabular}




\section{Illustrated cases:}

Fig. (1): 58 year-old-male patient with cough, expectoration, night fever and loss of appetite.

Fig. (1): (A) Plain X-ray chest PA view show radiolucent air space at the right upper lung zone. (B, C and D) Multislice CT axial view (lung \& mediastinal window) and coronal reformatting revealed right apical aircontaining cavitary lesion measuring about $5 \times 4.6 \mathrm{~cm}$ with surrounding multiple fibrotic bands. There is also overlying smooth apical pleural thickening measuring $9 \mathrm{~mm}$ at maximum thickness and no enlarged mediastinal lymph nodes. Bronchoscopic biopsy revealed: Pulmonary tuberculosis.
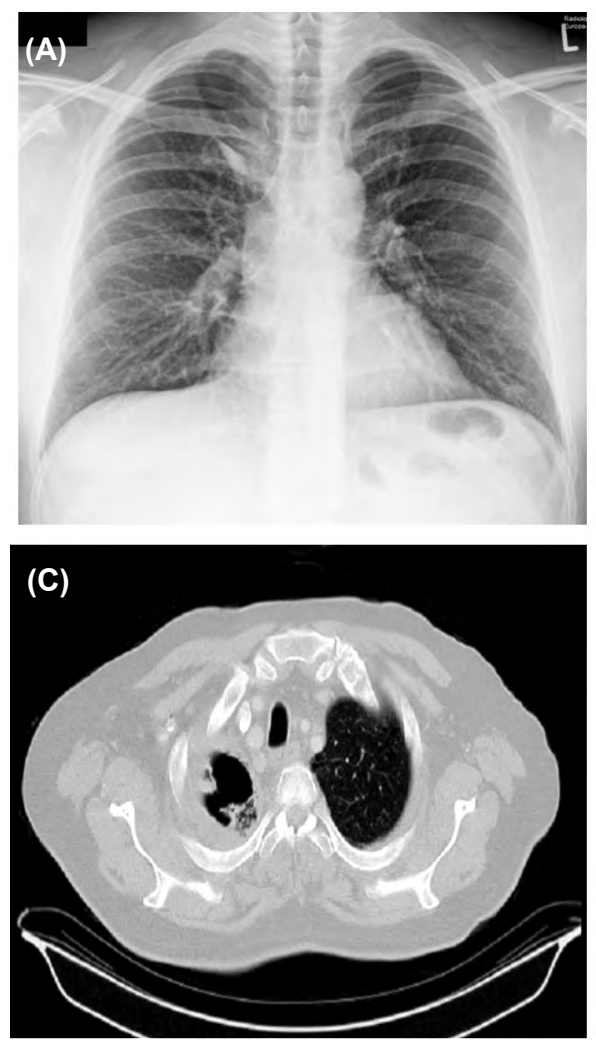
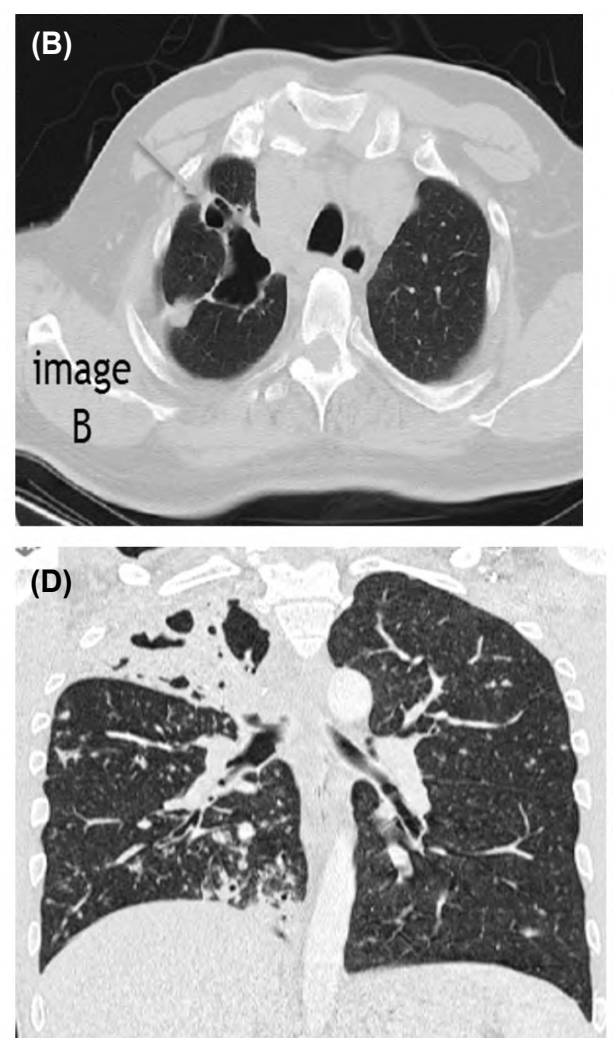

Fig. (2): 72 year-old-male patient with fever, chronic cough and expectoration.

Fig. (2): (A) Plain X-ray chest PA view show well defined cavitary lung lesion at the left lower lung lobe. (B and C) Multislice CT axial view (mediastinal \& lung window) revealed: Left apical segment lower lung lobe aircontaining cavitary lesion is seen measuring about $2.6 \mathrm{X}$ $2.4 \mathrm{~cm}$ (D) Multislice CT coronal view (lung window) with contrast revealed: Peripheral rim of enhancement is noted. Bronchoscopic biopsy revealed: Lung abscess.
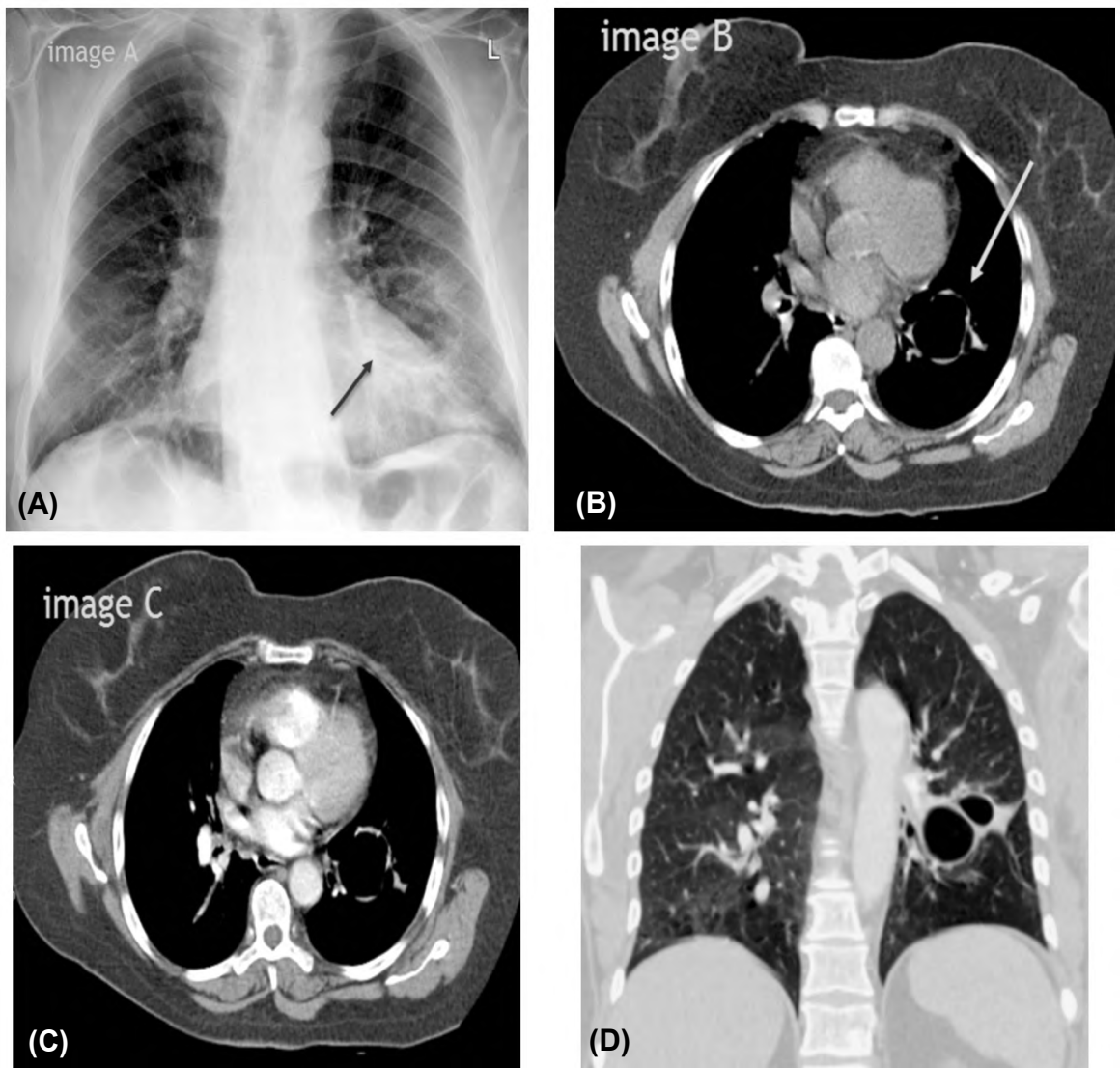
Fig. (3): 71 year-old-male patient with cough, hemoptysis and loss of appetite.

Fig. (3): (A) Plain X-ray chest PA view show heterogeneous cavitary lung lesion at the right lower lung zone. (B and C) Multislice $\mathrm{CT}$ axial view (lung \& mediastinal window) and coronal view (D) revealed: Well defined soft tissue mass is seen in the medial segment of the right lower lung lobe. This mass measures $6.8 \mathrm{X}$ $4.4 \times 4.5 \mathrm{~cm}$. Along its craniocaudal, antero-posterior and side to side dimensions respectively. This mass shows central cavitation with opening into right lower lobe bronchus, irregular thick speculated borders, no calcifications inside it and no CT evidence of pathologically enlarged hilar or mediastinal lymph nodes.bronchoscopic biobsy revealed bronchogenic carcinoma.
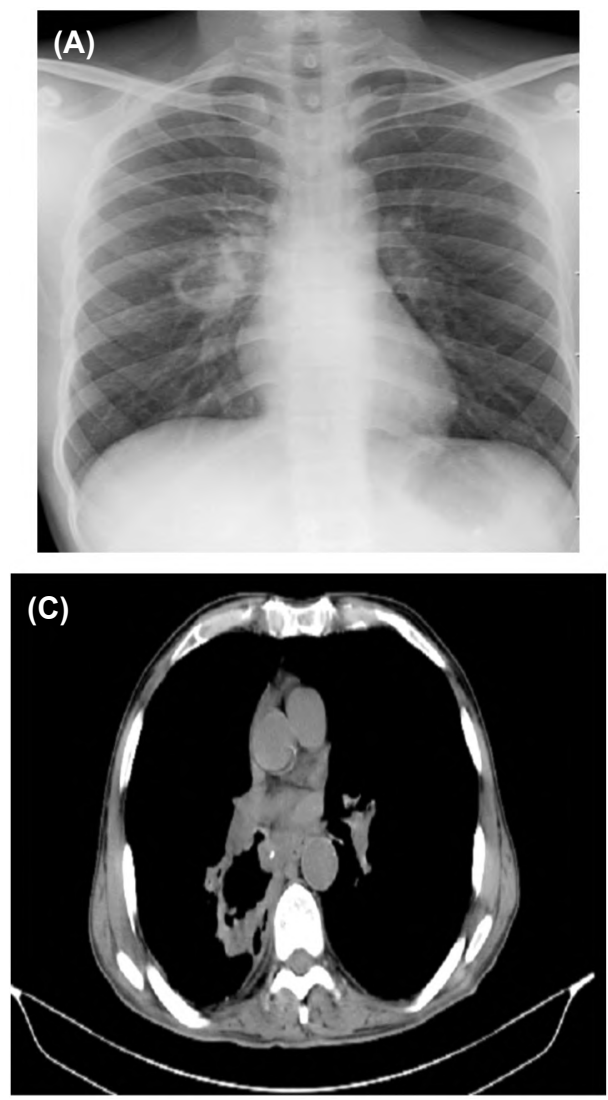
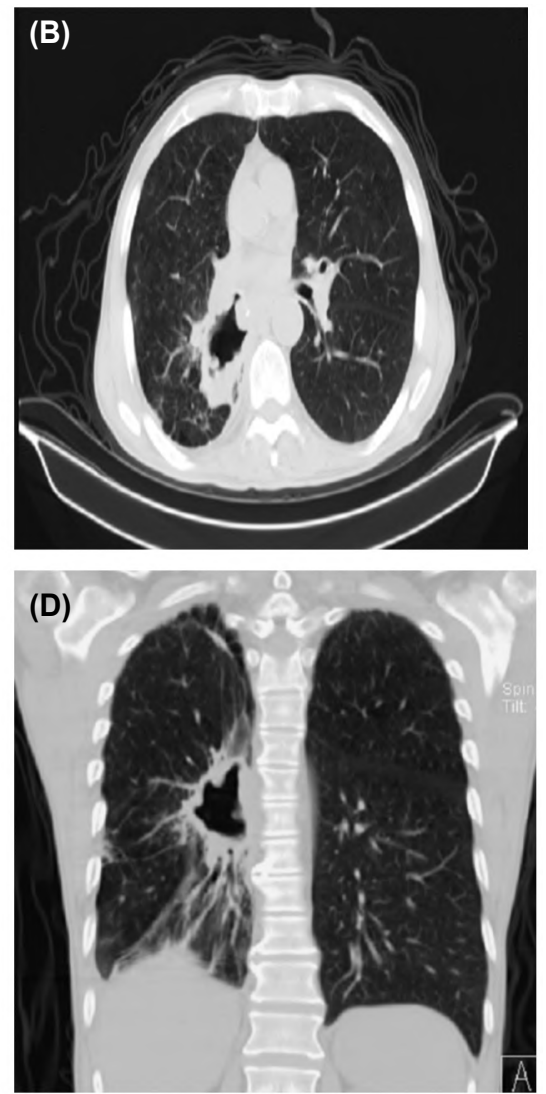

Fig. (4): 45 year-old-male patient with cough, expectoration and dyspnea.

Fig. (4): (A) Multislice precontrast $\mathrm{CT}$ axial view (lung window) (B) Multislice postcontrast CT axial view (mediastinal window) (C) Multislice $\mathrm{CT}$ coronal view (lung window) (D) Multislice CT sagittal view (lung window) revealed: Right upper lobe apical \& posterior segments air-containing cavitarylesionsare seen measuring about $4.2 \mathrm{X} 3 \mathrm{CM}, 3 \mathrm{X}$ $2 \mathrm{~cm}$ respectively surrounding with multiple fibrotic bands with no enlarged mediastinal Lymph nodes. Bronchoscopic biopsy revealed: Pulmonary mycetoma.
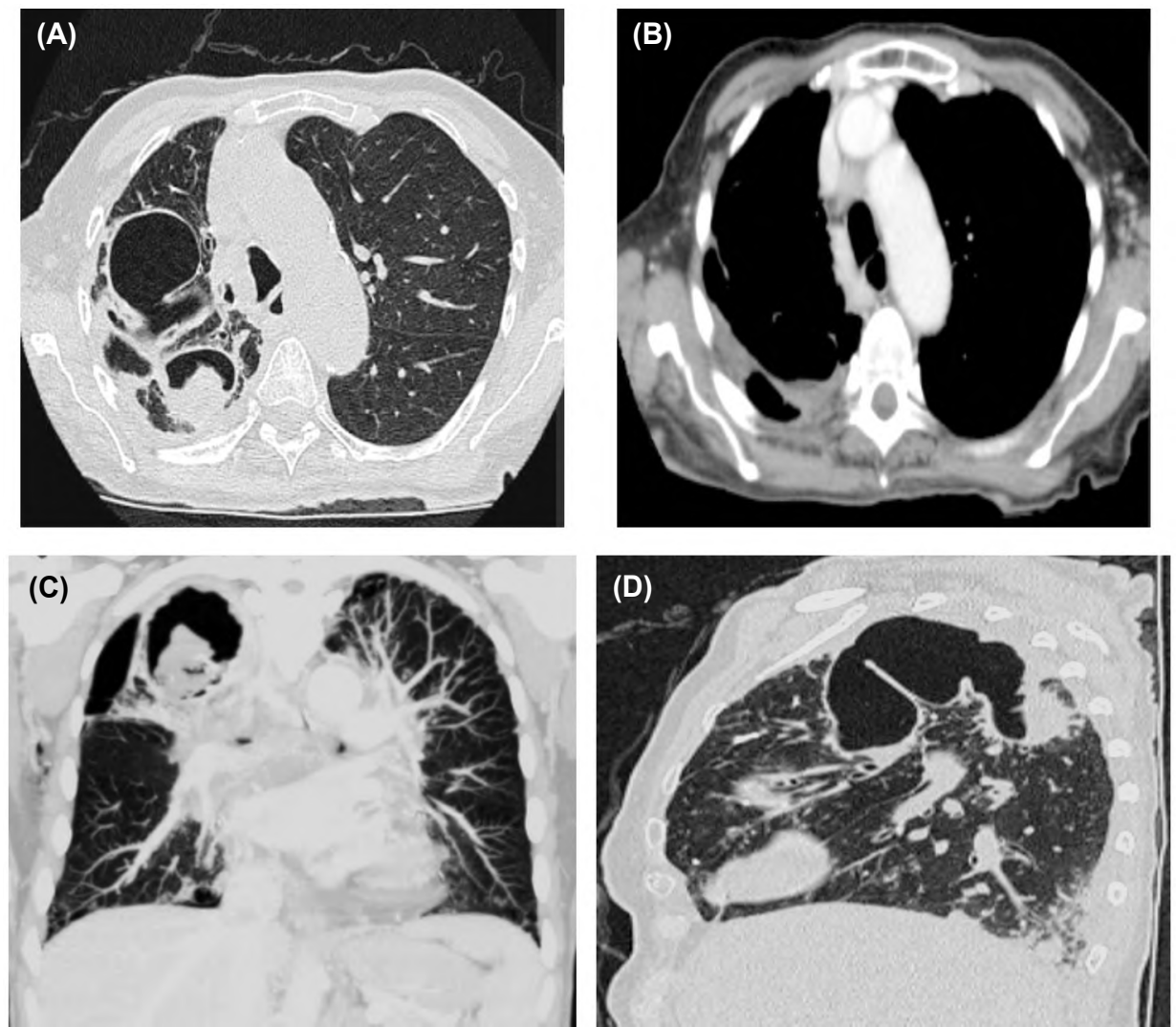


\section{Discussion}

Cavitary lesions are commonly encountered on chest radiography and chest computed tomography, the differential diagnosis of such lesions is broad because many reasons of congenital and acquired origin can cause these abnormalities. Cavities and cysts are seen as areas of decreased lung density with defined walls $[10,11]$

Cross-sectional imaging, such as Computed Tomography (CT) is frequently required for confirmation of diagnosis, also characterization and preoperative evaluation of surgical lesions. Recent rapid advancement in $\mathrm{CT}$ has allowed CT to play an important role in the non-invasive evaluation of lung diseases, in particular with multi-detector computed tomography with post processing techniques, including multiplanar reconstruction and 3-dimensional reconstructions [10]

In this study, the patient age ranging from 15 to 83 years, the most common age group is between 40 to 50 years $(25 \%)$, as regard the difference between males and females, the present study included 46 males (76\%) and 14 females (24\%). This is in agreement with El-Sabaa et al., 2010 [8] study as regard to the difference between male and female but differ in the commonest age group was between 60 and 70 years.

Concerning the clinical presentation vary between different cavitary lung lesions according to the etiology, for example constitutional manifestations such as fever, anorexia is matched more with abscess. Cough, expectoration, night sweat and weight loss matched more with tuberculosis and finally marked weight loss, anorexia with low grade fever matched more with malignancy.

This is in disagreement with Akinosoglou et al., 2013 [12]. Who reported that the acute onset of symptoms is sometimes helpful to distinguish malignant and nonmalignant disease, but a benign infection may, for instance, cause hemoptsis when affecting a nearby vessel. Benign diseases may also cause fatigue and weight loss similar to malignancies. Acute onset of fever is usually helpful to distinguish benign disorders from malignancies, but lung cancer may present with a superinfection secondary to the tumor. However, the combination of symptoms, laboratory results, clinical history, and imaging findings reaching the correct diagnosis.

Concerning the lung abscess is seen in 17 patients, the lesions showed well circumscribed thick walled with regular margin and filled with air and fluid with no speculations or irregularities. The surrounding parenchymal ground glass and consolidation was a common feature. This is in agreement with Reynolds et al., 2010 [13] who reported that abscesses were seen on CT as cavitary lesions with or without a fluid level. They may occur anywhere in the lungs. Usually, intermediate to thick wall thickness with a peripheral contrast enhancement and necrotizing center was visible.

12 patients with cavitating tuberculous lesions were encountered in this study; the lesions occupied an apical location. Multiple relatively thick walled air-filled cavities with surrounding ground glass opacity and Cicatrization of the adjacent parenchyma were seen. This is in agreement with Kim and Lee KS 2002 [14] who reported similar findings and agreed that it's essential to recognize the characteristic CT findings of cavitating tuberculosis that commonly involve the apical and posterior segments of the upper lobes, a variety of sequale and complications can occur in the pulmonary and extra pulmonary portions of the thorax in treated or untreated patients, residual thin walled cavities may be seen in both active and inactive disease.

Six fungal cavitary lesions were seen in our study, the lesions had thin to mildly thickened wall with an intra cavitary soft tissue mass. The lesion showed halo sign-complete or partially circumferential ground glass opacity of the lung parenchyma was seen in the adjacent to the lesion denoting reactive hemorrhage o the nearby parenchyma. An air crescent sign was also noted signifying a cleavage between infected necrotic lung tissue and the cavity's inner contour. Our study include 15 patients with neoplastic cavitary lesions, 11 cases had bronchogenic carcinoma and 4 patients with multiple cavitary neoplastic lung deposits. CT findings of all neoplastic lesions revealed that all were air filled and had thick walls with speculated margins infiltrating the surrounding lung parenchyma.

Our study is in agreement with Ryu \& Swensen 2003 [15] who reported that the most commonly encountered solitary cavitary nodule in the lung is a malignant tumor they may occur anywhere in the lungs and have round or irregular shapes with a great variation in wall thickness. Wall thickness greater than $24 \mathrm{~mm}$ as well as perilesional consolidation may indicate malignancy, as mentioned earlier of all bronchial carcinomas; 10-15 percent are cavitary.

In this study MDCT was able to differentiate between benign and malignant cavitary lung lesions. Benign lesions were seen in 45 patients 
categorized as 10 patients having airway diseases $\& 35$ patients having infective lung lesions, these lesions have relatively well defined lesions with wall thickness less than $4 \mathrm{~mm}$ seen in 22 patient of airway diseases and wall thickness between 4 to $10 \mathrm{~mm}$ seen in 30 patients of infective lung lesions, however malignant lung lesions seen in 15 patients with wall thickness more than $10 \mathrm{~mm}$ which seen in 8 patients having neoplastic process. In agree with Guo et al., 2016 [16] who reported that the wall thickness of the cavitary lung lesions in solitary disease can be useful in differentiating between benign and malignant disorders. They reported that a wall thickness of less than $7 \mathrm{~mm}$ was highly specific for benign disease, and thickness of greater than $24 \mathrm{~mm}$ was highly specific for malignant disease.

In our study, 2 cases had false positive results by CT could be explained by: One out of two had relatively ill defined borders with slightly speculated margin and rather regular outlines mistaken as benign looking well defined cavitary lung lesion with smooth margin and regular borders, while the remaining case explained by wall thickness measuring about $9 \mathrm{~mm}$ mistaken as infective cavitary lung lesions with wall thickness ranging between 4 and $10 \mathrm{~mm}$. One case had false negative results by CT could be explained by rather well defined lesion with wall thickness measuring about $10.5 \mathrm{~mm}$ surrounded by multiple consolidative patches and atelectatic bands.

In our prospective study, multislice computed tomography showed sensitivity of $91 \%$, specificity of $88 \%$, and accuracy of $87 \%$ Quint et al., 2006 [17] reported in a study of 226 a diagnostic sensitivity, accuracy, and negative predictive value in the diagnosis of malignancy of $91 \%, 92 \%$, and $68 \%$, respectively. Loh et al., 2013 [18] reported a diagnostic sensitivity, accuracy, and negative predictive value of CT imaging for malignant lesion of $96 \%, 97 \%$, and $88 \%$, respectively.

\section{Conclusion:}

MDCT is superior to plain X-ray in demonstrating the cavitary lung lesions with higher degree of clarity. It can define the exact anatomical site of the cavity, characterization of the cavitary wall and abnormalities in the surrounding lung parenchyma. It is reliable in detecting lesions in areas difficult to visualize by plain X-ray.

\section{Competing interests:}

The authors declare that they have no competing interests.

\section{References}

1- SEO H., CHA S.I., SHIN K.M., et al.: Focal necrotizing pneumonia is a distinct entity from lung abscess. Respirology, 18: 1095-100, 2013.

2- YAZBECK M.F., DAHDEL M., KALRA A., et al.: Lung abscess: Update on microbiology and management. Am. J. Ther., 21: 217-21, 2014.

3- LIN F.C., CHOU C.W. and CHANG S.C.: Differentiating pyopneumothorax and peripheral lung abscess: Chest ultrasonography. Am. J. Med. Sci., 327: 330-5, 2004.

4- KIYOMI FURAYA, KOTARO YASUMORI, SADANORI TAKEO, et al.: Lung CT: Part 1, mimickers of lung cancer -spectrum of CT findings with pathologic correlation. A.J.R., 199: W454-W463, 2012.

5- REBECCA M. LINDELL, THOMAS E. HARTMAN, STEPHEN J. SWENSON, et al.: Five year lung cancer CT appearance: CT appearance, growth rate, location and histologic features of 61 lung cancers. Radiology February, 242 (2): 555-62, 2007.

6- FENG LI, SHUSUKE SONE, HIROYUKI ABE, et al.: Malignant versus benign nodules at CT screening for lung cancer: Comparison of thin section CT findings. Radiology, 233: 793-8, 2004

7- GADKOWSKI L.B. and STOUT J.E.: Cavitary Pulmonary Disease. Clinical Microbiology Reviews. Volume 21, Number 2, pp. 305-33, 2008.

8- EL-SABAA A.Y., FATHI A.M., ATTA M.S., et al.: The role of multidetector computed tomography in the assessment of cystic and cavitary pulmonary lesions. Alexandria Bulletin, 46: 2, 2010

9- KIM N.R. and HAN J.: Pathologic review of cystic and cavitary lung diseases: Korean J. Pathol., 46 (5): 407-14, 2012.

10- VERSCHAKELEN J.A. and WEVER W.D.: Chapter 2 Basic Anatomy and CT of the Normal Lung. In Leuven A.L., Gottingen M., Heidelberg K. et al. Computed Tomography of the lung A pattern Approach. Germany, Spring er-Verlag Berlin Heidelberg, pp. 2-16, 2007.

11- BEIGELMAN-AUBRY C., HILL C., GUIBAL A., et al.: Multidetector row $\mathrm{CT}$ and post processing technique in assessment of diffuse lung diseases. Radiographics, 25: 1639-52, 2005

12- AKINOSOGLOU K.S., KARKOULIAS K. and MARANGOS M.: Infectious complications in patients with lung cancer. Eur. Rev. Med. Pharmacol. Sci., 17: 8-18, 2013.

13- REYNOLDS J.H., McDONALD G., ALTON H. and GORDON S.B.: Pneumonia in the immunocompetent patient. Br. J. Radiol., 83: 998-1009, 2010.

14- YOUNG C.Y., LEE K.S., KIM T.S., et al.: Intrapulmonary bronchogenic cyst: $\mathrm{CT}$ and pathologic findings in Five Adult Patients. A.J.R., 179: 167-70, 2002.

15- RYU J.H. and SWENSEN S.J.: Cystic and cavitary lung diseases: Focal and diffuse. Mayo Clinic Proc., 78 (6): 744-52, 2003 
16- GUO J., LIANG C., SUN Y., ZHOU N., LIU Y. and CHU $\mathrm{X}$.: Lung cancer presenting as thin-walled cysts: An analysis of 15 cases and review of literature. Asia Pac. J. Clin. Oncol., 12: 105-12, 2016.

17- QUINT L.E., KRETSCHMER M., CHANG A. and NAN
B.: CT-guided thoracic core biopsievalue of a negative result. Cancer Imaging, (6): 163-7, 2006.

18- LOH S.E., WU D.D., VENKATESH S.K., et al.: CTguided thoracic biopsy: Evaluating diagnostic yield and complications. Ann. Acad. Med. Singapore, 42 (6): 285 90, 2013.

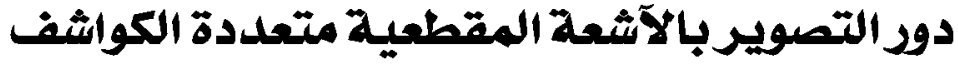 فى التفرقة بين التكهفات الرئوية الحميدة والحفيدة والخبيثة}

إشتملت هذه الرسالة على ستين مريضا، ستة وآربعقن ذكرا آربعة عشر آنثى بمتوبسط آعمار من خمسة عشر إلى ثلاثة وثمانين عاما (متوبسط العمر بين آربعين إلى خمسين عاما الرسا ).

خضع كل المرضى للفحص الإكلينيكى المفصل متضمنا التاريخ المرضى وكذلك الفحص بالآشعة العادية والآثـعة المقطعية متعدة الكواشف. إيجازا فإن الفحص بالآشعة المقطعية متعددة الكواشف آظهر نتائج مميزة فى التفرقة بين التكهفات الرئوية الحميدة والخبيثة ويدرجات فاقت الفحص بالآشعة العادية.

ولذلك فإن الفحص بالآثعة المقطعية متعددة الكواشف يجب آن يكن الفحص الآولى لتقيم والتفرقة بين التكهفات الرئوية الحميدة منها 